\title{
Preparation and Biopharmaceutical Evaluation of Novel Polymeric Nanoparticles Containing Etoposide for Targeting Cancer Cells
}

\section{Kanser Hücrelerini Hedefleyen Etopozit İçeren Yeni Polimerik Nanopartiküllerin Hazırlanması ve Biyofarmasötik Değerlendirmesi}

\author{
(D) Ayyappan THIYAGARAJAN1,2*, (D) Shanmugam SARAVANABHAVAN1, (D) Vetrichelvan THANGARASU3 \\ 1Adhiparasakthi College of Pharmacy, Department of Pharmaceutics, Tamil Nadu, India \\ 2Research Scholar, The Tamil Nadu Dr. M.G.R. Medical University, Chennai, India \\ ${ }^{3}$ Adhiparasakthi College of Pharmacy, Department of Pharmaceutical Analysis, Tamil Nadu, India
}

\begin{abstract}
Objectives: Polymeric nanoparticles are a promising novel drug delivery system and have advantages in cancer therapy. Etoposide is an anticancer agent that is used in the treatment of a variety of malignancies. The aim of the present study was to prepare and evaluate novel polymeric nanoparticles containing etoposide.

Materials and Methods: A $3^{2}$ full factorial design was used to study the effect of Eudragit EPO and Pluronic F-68 on the characterization of nanoparticle suspensions. The polymeric nanoparticles were prepared by nanoprecipitation technique. The prepared nanoparticles was evaluated by percentage yield, drug polymer compatibility using fourier transform infrared (FTIR) spectroscopy and differential scanning calorimetric (DSC) analysis, drug content, entrapment efficiency, zeta potential, particle size, scanning electron microscopy, X-ray diffraction, in vitro drug release studies, kinetic modeling, stability studies, and in vivo animal studies. Response surface plots were studied, which were generated using PCP dissolution software.

Results: Scanning electron microscopic studies confirmed their porous structure with a number of nanochannels. The FTIR spectra showed the stable character of etoposide in a mixture of polymers and revealed the absence of drug-polymer interactions. The DSC study revealed that the drug was involved in complexation with nanoparticles. The average particle size of etoposide nanoparticles was in the range of $114.4 \mathrm{~nm}$ to 136.7 $\mathrm{nm}$. The zeta potential values were attained to ensure good stability of nanosuspensions. In vitro release of the drug from nanoparticles follows the Peppas model and showed controlled release behavior for a period of $24 \mathrm{~h}$. The optimized nanoparticles were subjected to stability studies at $4^{\circ} \mathrm{C}$ in a refrigerator and the most suitable temperature for storage of etoposide nanoparticles found. The average targeting efficiency of drugloaded nanoparticles was $41.88 \pm 0.030 \%$ of the injected dose in the liver, $25.66 \pm 0.320 \%$ in the spleen $13.82 \pm 0.090 \%$ in the lungs, $4.52 \pm 0.300 \%$ in the kidney, and $4.18 \pm 0.490 \%$ in the brain.
\end{abstract}

Conclusion: Etoposide loaded nanoparticles was found to be effective in sustained release.

Key words: Etoposide, Eudragit EPO, pluronic F-68, $3^{2}$ full factorial design, nanoparticles

öz

Amaç: Polimerik nanopartiküller kanser tedavisinde avantajlı ve gelecek vaad eden yeni ilaç salım sistemidir. Etopozid, çeşitli malignitelerin tedavisinde kullanılan bir antikanser ajanıdır. Bu çalıșmanın amacı, etopozit içeren yeni polimerik nanopartiküllerin hazırlanması ve değerlendirilmesidir.

Gereç ve Yöntemler: Eudragit EPO ve Pluronic F-68'in nanopartikül süspansiyonunun karakterizasyonu üzerindeki etkisini incelemek için $3^{2}$ tam faktöriyel tasarım kullanılmıştır. Polimerik nanopartiküller nano presipitasyon tekniği ile hazırlanmıştır. Hazırlanan nanopartiküller, yüzde verim, fourier dönüșümü kızılötesi (FTIR) spektroskopisi ve diferansiyel taramalı kalorimetrik (DSC) analizi kullanılarak ilaç polimer uyumluluğu, etkin madde içeriği, yükleme kapasitesi, zeta potansiyeli, partikül boyutu, taramalı elektron mikroskobu, X-ışını difraksiyon, in vitro etkin madde salım

*Correspondence: E-mail: tayyaps@yahoo.co.in, Phone: 919894567170

Received: 08.12.2017, Accepted: 25.01.2018

๑Turk J Pharm Sci, Published by Galenos Publishing House. 
çalışmaları, kinetik modelleme, stabilite çalışmaları ve in vivo hayvan çalışması ile değerlendirilmiştir. PCP çözünme yazılımı kullanılarak oluşturulan tepki yüzey grafikleri incelenmiştir.

Bulgular: Taramalı elektron mikroskopisi çalışmaları çok sayıda nano-kanal içeren gözenekli yapılarını doğrulamıștır. FTıR spektrumları, polimer karışımında etopozitin stabil olduğunu ve ilaç polimer etkileşimlerinin olmadığını ortaya çıkartmıştır. DSC çalışması, etkin maddenin komplikasyon ile nanopartiküllere yüklendiğini ortaya koymuștur. Etopozid nanopartiküllerin ortalama partikül büyüklüğünün $114.4 \mathrm{~nm}$ ile $136.7 \mathrm{~nm}$ arasında olduğu bulunmuştur. Zeta potansiyel değerlerinden elde edilen sonuç nanosüspansiyonların iyi bir stabilitede olmasını sağlamıştır. Nano-partiküllerden etkin maddenin in vitro salımı Peppas'a uyumlu olup, 24 saatlik bir süre boyunca kontrollü salım göstermiştir. Optimize edilmiş nanopartiküller, $4^{\circ} \mathrm{C}$ 'de buzdolabında stabilite çalıșmalarına tabi tutulmuș ve Etopozid nanopartiküllerinin depolanması için en uygun sıcaklık olarak bulunmuștur.

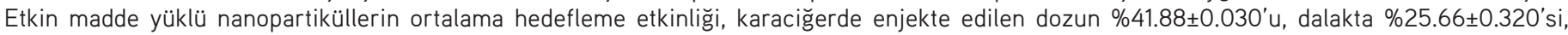
akciğerlerde \%13.82 \pm 0.090 'ı, böbreklerde $\% 4.52 \pm 0.300$ 'ü ve beyinde $\% 4.18 \pm 0.490$ ' olarak bulunmuștur.

Sonuç: Etopozit yüklü nanopartiküllerin sürekli salımda etkili olduğu sonucuna varılmıştır.

Anahtar kelimeler: Etopozit, Eudragit EPO, pluronic F-68, 32 tam faktöriyel tasarım, nanopartiküller

\section{INTRODUCTION}

Cancer is a major public health problem around the world. There were 14.1 million new cancer cases and 8.2 million cancer deaths in 2012 worldwide. If these rates do not change, the global cancer burden is expected to nearly double to 21.4 million cases and 13.5 million deaths by 2030 . Breast cancer is the most common cancer among women worldwide, with nearly 1.7 million new cases diagnosed in 2012 (the second most common cancer). This represents about $12 \%$ of all new cancer cases and $25 \%$ of all cancers in women. Cancer is the second leading cause of death worldwide, and was responsible for 8.8 million deaths in 2015. According to the WHO, nearly 1 in 6 deaths is due to cancer.

A typical example of topoisomerase inhibitors is etoposide and it is a first-line chemotherapeutic agent used in the treatment of many types of cancer. The mechanism of action of etoposide is by forming a ternary complex with topoisomerase II and DNA, causing DNA breaks and cell death.' However, there are many side effects related to the drug, ${ }^{2-4}$ and the administration of etoposide is rate limited by its low solubility in aqueous solutions. 5,6 Therefore, finding an effective approach to facilitate the transport of drugs and to improve the bioavailability of therapeutics is necessary.

The drug candidate etoposide has variable oral bioavailability ranging from $24 \%$ to $74 \%$ and has a terminal half-life of $1.5 \mathrm{~h}$ by intravenous route and $0.44 \mathrm{~h}$ by oral route. Conventional oral therapy has the drawback of low bioavailability and parenteral therapy causes inconvenience and pain to the patients as it has to be given through a continuous IV infusion over 24-34 h.

Hence, the aim of the present study was to prepare and evaluate formulations of Eudragit EPO-based nanoparticles. A nanoparticle suspension was prepared by nanoprecipitation technique using Eudragit EPO. Eudragit EPO is a cationic nonbiodegradable synthetic polymer that is used for the design of controlled drug delivery systems. Moreover, $3^{2}$ factorial designs are widely used to study the effect of Eudragit EPO and Pluronic F-68 on the characterization of nanoparticle suspensions. The optimized formulation was subjected to lyophilization. The prepared nanoparticles were characterized with respect to particle size and surface morphology, surface charge-zeta potential, drug content, entrapment efficiency, in vitro drug release studies, kinetic modeling, stability studies, and animal study like biodistribution studies.

\section{MATERIALS AND METHODS}

\section{Materials}

Etoposide was a gift sample from Biocon Limited, Bangalore, India; Eudragit ${ }^{\circledR}$ EPO and HPMC K-15 were gifts from Cipla Pharmaceuticals, Mumbai, India. Pluronic ${ }^{\circledR}$ F-68 was gifted by Alembic Pharmaceuticals, Mumbai, India. Synthetic cellulose membrane (mol. cut-off value 12,000) was procured from Himedia Labs, Mumbai, India. All other reagents and chemicals used in this study were of analytical grade.

\section{Solubility study}

The solubility profile of etoposide was established by different solvent systems such as methanol and purified water as per the standard procedure.

\section{Preparation of Eudragit EPO-based nanoparticle suspension}

Nanoparticle suspensions were prepared by nanoprecipitation. First $50 \mathrm{mg}$ of the drug and a specific amount of Eudragit ${ }^{\circledR}$ EPO were dissolved in $15 \mathrm{~mL}$ of methanol. The organic solution was quickly injected into $40 \mathrm{~mL}$ of aqueous solution containing Pluronic ${ }^{\circledR} \mathrm{F}-68$ under stirring at 2000 rpm. Stirring was continued for $2 \mathrm{~h}$ at $40^{\circ} \mathrm{C}$ for the evaporation of methanol. The volume was adjusted up to $40 \mathrm{~mL}$ with aqueous solution of $200 \mathrm{mg}$ of HPMC K-15 to obtain a nanoparticle suspension. The optimized nanoparticle suspension was lyophilized at $-42^{\circ} \mathrm{C}$ for $72 \mathrm{~h}$ and also redispersed in water to get an aqueous nanoparticle suspension. ${ }^{7}$ Blank nanoparticles were prepared under the same conditions without the drug.

\section{Formulation design by $3^{2}$ factorial design techniques}

Prior knowledge and understanding of the process and the variable under investigation led to preliminary experiments. Based on the preliminary data, a $3^{2}$ factorial design was used to optimize the amount of Eudragit ${ }^{\circledR}-E P O(X 1)$ and Pluronic ${ }^{\circledR}$ F-68 (X2) and identify the independent variable affecting the drug content and the percentage drug encapsulation efficiency (dependent variable). The response surfaces of the obtained results were plotted. The coded and the actual values of the experimental design are given in Table 1. The data obtained from various batches for drug content and entrapment efficiency were subjected to multiple regression analysis using PCP dissolution software, and the equation fitted was;

Response $Y=\beta_{0}+\beta_{1} X_{1}+\beta_{2} X_{2}+\beta_{11} X_{1}^{2}+\beta_{22} X_{2}^{2}+\beta_{12} X_{1} X_{2} \ldots .$. (1) 
Where $y$ is the measured response, $X$ is the level of factors, and $\beta$ is the coefficient computed from the responses of the formulations (quadratic form).

Physical mixtures of the drugs, Eudragit EPO, Pluronic F-68, and HPMC K-15, were prepared by dry blending using the same ratios as used for the preparation of the optimized batch of nanoparticle suspension.

\section{Characterization of nanoparticles}

Practical yield

Percentage practical yield ${ }^{8}$ is calculated to know about the efficiency of the method. Thus it helps in selection of an appropriate method of production. Practical yield was calculated as the weight of nanoparticles recovered from each and every batch in relation to the sum of the starting material. The percentage yield of prepared nanoparticles was calculated by practical yield/theoretical yield $\times 100$.

\section{Compatibility studies}

\section{a) Fourier transform infrared spectroscopy}

The fourier transform infrared (FTIR) spectra of the drug ${ }^{9}$ and lyophilized nanoparticles were determined using a Shimadzu FTIR-801 spectrophotometer. The pellets were prepared by gently mixing a $10 \mathrm{mg}$ sample with $200 \mathrm{mg}$ of potassium bromide at high compaction pressure. Baseline correction was performed using dried potassium bromide and the spectra of a dried mixture of drug and polymers were recorded. The prepared pellets were scanned at a resolution from $4000 \mathrm{~cm}^{-1}$ to $400 \mathrm{~cm}^{-1}$.

\section{b) Differential scanning calorimetry}

Differential scanning calorimetry (DSC) studies were performed using a differential scanning calorimeter (Shimadzu W70 thermal analyzer) to determine the thermal behavior of the drug and lyophilized nanoparticles. Then $5 \mathrm{mg}$ samples were weighed into aluminum pans and heated in these hermetically sealed pans in the temperature range of $100-300^{\circ} \mathrm{C}$ at a heating rate of $10^{\circ} \mathrm{C} / \mathrm{min}$ under nitrogen flow of $30 \mathrm{~mL} / \mathrm{min} .^{10}$

\section{Estimation of drug content}

Accurately weighed amounts equivalent to $10 \mathrm{mg}$ of each batch of polymeric nanoparticles were dissolved in methanol. The solution was filtered using a $0.45 \mu \mathrm{m}$ Millipore filter as per the reported method. The drug content was estimated using a UV-visible spectrophotometer (Shimadzu UV-1700) at 286 $\mathrm{nm}$ against a blank solvent system containing the same concentration of drug in the formulation. ${ }^{11}$

$\%$ drug content $=\frac{\text { Amount of drug found }}{\text { Label claim }} \times 100$

\section{Estimation of entrapment efficiency}

The entrapment efficiency of the prepared formulation was determined by measuring the concentration of free drug in the dispersion medium. The entrapped drug was determined by adding $1 \mathrm{~mL}$ of nanosuspension to $9 \mathrm{~mL}$ of methanol in order to dissolve the entrapped drug. The nanoparticle suspension needed to be centrifuged for $2 \mathrm{~h}$ at 14,000 rpm. The supernatant liquid was separated and filtered through a $0.45 \mu \mathrm{m}$ Millipore filter. The filtrate was diluted with the solvent system and measured spectrophotometrically (Shimadzu UV-1700). Entrapment efficiency was calculated using the following equation: ${ }^{12}$

$\%$ drug entrapment efficiency $=\frac{W \text { initial drug }-W \text { free drug }}{W \text { initial drug }} \times 100$

\section{Particle size analysis}

Particle size analysis of nanoparticles was performed by photon correlation spectroscopy. This technique yields the mean particle diameter and particle size distribution. ${ }^{13}$ Lyophilized nanoparticles were analyzed using a Mastersizer 2000 (Malvern Instruments, Malvern, UK).

\section{Scanning electron microscopy analysis}

The shape and surface morphology of nanoparticles was studied using scanning electron microscopy (SEM). SEM analysis was used to determine particle shape, surface topography, and texture and to examine the morphology of the fractured structure. A small volume of nanoparticle suspension was mounted on metal stubs using double-sided tape and coated with gold under a vacuum. The stub was visualized under a scanning electron microscope. ${ }^{14}$

\section{Zeta potential measurement}

The surface of particles in suspension develops a charge due to adsorption of ions or ionization of surface groups and the charge is correspondingly dependent on both the surface chemistry and environment of the particles. The zeta potential was determined by zeta potentiometer. A sample was placed into the cell; an electrode inserted was placed under the microscope and connected to the zeta meter. The electrode was energized and the colloids were watched to move across a grid in the microscope's eye piece. A colloid is tracked by simply pressing the track button and holding it down while the colloid traverses the grid. When the track button is released, the zeta meter instantly calculates and displays the colloid's zeta potential (Zetasizer, Malvern, UK). ${ }^{13}$

\section{$X$-ray diffractometry analysis}

The X-ray diffraction pattern of the drug and lyophilized nanoparticles was recorded using a Philips X-ray diffractometer with copper target. The conditions were as follows: voltage 30 $\mathrm{kV}$; current $30 \mathrm{~mA}$; scanning speed $-1 \% \mathrm{~min}$; temperature of acquisition: room temperature; detector: scintillation counter detector; sample holder: nonrotating holder. ${ }^{7}$

\section{In vitro drug release study}

The in vitro drug release of the drug, physical mixture, and lyophilized nanoparticles was determined using the dialysis membrane method. ${ }^{15}$ The formulation equivalent to $50 \mathrm{mg}$ of drug was poured into dialysis bags (with a cut-off of 12,000 $\mathrm{Da}$, Sigma). The dialysis bag was suspended in a beaker containing $100 \mathrm{~mL}$ of phosphate buffer at $\mathrm{pH} 7.4$ on a magnetic stirrer at $100 \mathrm{rpm}$, with temperature adjusted to $37 \pm 0.5^{\circ} \mathrm{C}$ at 
a selected time interval. A $5 \mathrm{~mL}$ sample was removed and replaced with fresh medium. The sample was filtered through a $0.45 \mu \mathrm{m}$ Millipore filter. The samples were analyzed for drug release by measuring absorbance at $286 \mathrm{~nm}$ using a UV-visible spectrophotometer (Shimadzu UV-1700). The rate of etoposide release was obtained using the standard curve.

\section{Kinetics of in vitro drug release}

PCP dissolution software was used to study the mechanism and kinetics of drug release from etoposide nanoparticles. The data obtained from the in vitro release study were entered into PCP dissolution software to study the various kinetic equations like zero order (\% cumulative drug release vs time), first order (log\% cumulative drug remaining vs time), and Higuchi matrix (\% cumulative drug release vs square root of time). In order to define a model that will represent a better fit for the formulation, the drug release data were further analyzed by the Peppas equation. The value of $n$ indicates a measure of the primary mechanism of drug release. $R^{2}$ values were calculated for the linear curves obtained by regression analysis.

\section{Statistical analysis}

Prior knowledge and understanding of the process and the variable under investigation led to preliminary experiments. Based on the preliminary data, the $3^{2}$ factorial design was adopted to optimize the amount of Eudragit ${ }^{\circledR}$-EPO (X1) and Pluronic ${ }^{\circledR}$ F-68 (X2) and identify the independent variable affecting the drug content and the percentage drug encapsulation efficiency (dependent variable). The response surfaces of the obtained results were plotted. The values obtained from various batches for drug content and encapsulation efficiency were subjected to multiple regression analysis using PCP dissolution software and the equation fitted was;

$$
Y: \beta_{0}+\beta_{1} X_{1}+\beta_{2} X_{2}+B_{11} X_{12}+\beta_{22} X_{2}+\beta_{12} X_{1} X_{2} \ldots 1
$$

Where $Y$ is the measured response, $X$ is the level of factors, and $\beta$ is the coefficient computed from the responses of the formulations.

\section{Stability studies}

The stability studies of the optimized nanoparticles were evaluated $^{16}$ by storing the formulation at $4 \pm 1^{\circ} \mathrm{C}$ in a refrigerator as per $\mathrm{ICH}$ guidelines. The nanoparticles were stored in screw capped amber-glass bottles. Physical instability like change in appearance and settling behavior was also observed. The sample was withdrawn and analyzed for its drug content, drug entrapment efficiency, and in vitro drug release profile.

\section{In vivo drug targeting studies}

The experimental protocol was approved by the institutional Animal Ethical Committee (APCP/IAEC/409/01) prior to the start of the animal studies. The experiments were performed in accordance with the current guidelines of the CPCSEA.

Healthy rats weighing 200-250 g were selected. A constant day and night cycle was maintained and they were fasted for $12 \mathrm{~h}$. The animals are divided into 3 groups, each containing 6 rats.
Group I rats were treated as controls (received orally $0.5 \%$ CMC dispersion only);

Group II rats received $9 \mathrm{mg} / \mathrm{kg}$ etoposide given orally after redispersal in $0.5 \%$ CMC dispersion;

Group III rats received nanoparticles equivalent to $9 \mathrm{mg} / \mathrm{kg}$ of etoposide given orally after redispersal in 0.5\% CMC dispersion; optimized formulation (F6) was selected for the study.

After $24 \mathrm{~h}$ the rats were sacrificed and their liver, lungs, spleen, kidney, heart, and brain were isolated. Individual organs of each rat were homogenized separately using a tissue homogenizer. The tissue homogenate was made using methanol, and $1.2 \mathrm{~mL}$ of tert-butyl methyl ether was mixed with a $0.1 \mathrm{~mL}$ aliquot of the tissue sample in a $2.0 \mathrm{~mL}$ polypropylene microtube. Then the homogenate was centrifuged at 15,000 rpm for $30 \mathrm{~min}$. The supernatant liquid was collected and filtered through $0.22 \mu \mathrm{m}$ filters and samples were analyzed by HPLC system.

\section{RESULTS AND DISCUSSION}

Spectral data of etoposide sample and standard etoposide confirmed the identity of the compound as etoposide. The solubility of etoposide in $10 \mathrm{mg} / 10 \mathrm{~mL}$ solvent was tested and it revealed that it was freely soluble in methanol and poorly soluble in water (less than $\mathrm{mg} / \mathrm{mL}$ ) at $37^{\circ} \mathrm{C}$. Nanoprecipitation technology was selected for the production of submicron particles complying with the low aqueous solubility of etoposide. On the basis of drug solubility and miscibility in the aqueous phase, methanol was selected as the solvent. The rapid diffusion of methanol from dispersed droplets into the aqueous phase with subsequent evaporation leads to fast precipitation of dissolved drug and polymer in the form of nanoparticles. ${ }^{17}$

The drug content and encapsulation efficiency of the nanoparticle suspensions were in the range of $61 \%$ to $89 \%$ and $48 \%$ to $94 \%$, respectively (Tables 1 and 1a), which were mainly influenced by polymer concentration. A curvilinear relation was observed between the drug content and encapsulation efficiency with Eudragit ${ }^{\circledR}$ EPO concentration. It can be explained on the basis of the lipophilic-lipophilic interaction between etoposide and Eudragit ${ }^{\circledR}$ EPO. Consequently, with an increase in the Eudragit ${ }^{\circledR}$ EPO amount, etoposide gets preferentially dispersed in the internal organic phase. ${ }^{18}$ Pluronic ${ }^{\circledR} \mathrm{F}-68$ also displayed a similar trend and an increase in encapsulation efficiency, which can be due to the formation of an interpenetrated network chain between the hydrophobic portions of Pluronic ${ }^{\circledR}$ F-68 with Eudragit ${ }^{\circledR}$ EPO during precipitation (synergistic effect evidenced from a positive coefficient value for the $\mathrm{X} 1 \mathrm{X} 2$ interaction term). ${ }^{19}$ It is confirmed by the positive regression values of the X1X2 term as shown in Table 1a. Particle size also showed similar effects. The influence of polymer-polymer interaction as compared to polymer-pluronic interaction signifies the stabilizing effect of the latter by minimizing the dispersion and distribution of drug outside the matrix. In this research, two responses were evaluated, and each response was plotted in relation to the modified factor. Both the experimental design and the linearity and response surface plots for drug content and encapsulation efficiency are shown in Figures 1a and 1b. 

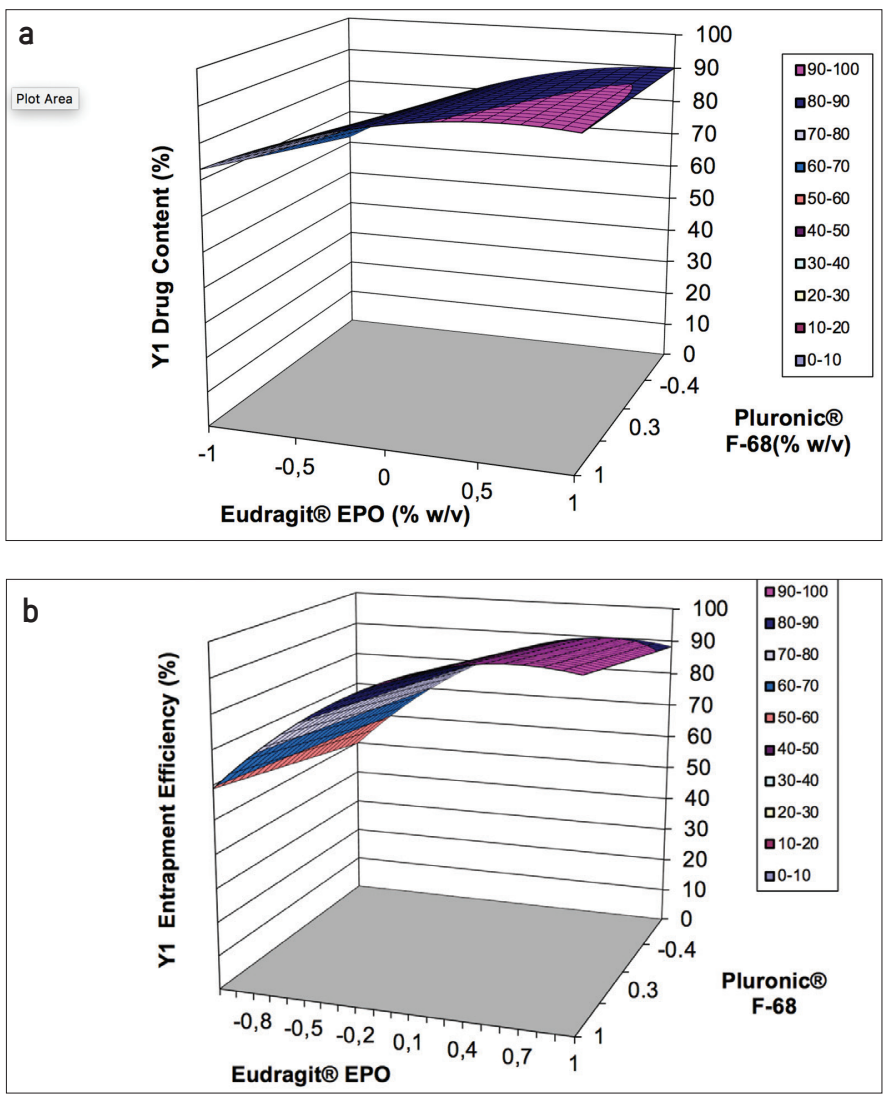

Figure 1. Response surface plot showing the influence of polymer surfactant ratio on drug content (a), Response surface plot showing the influence of polymer surfactant ratio on encapsulation efficiency (b)
As shown in Table 2, particle size of the nanoparticle suspension was in the range of 114 to $136 \mathrm{~nm}$, which was almost smaller than the etoposide $(1120 \mathrm{~nm})$. An increase in particle size of the nanoparticle suspension with a decrease in polydispersity index was observed with an increase in polymer content. The smaller particle size obtained at low polymer content may be due to high distribution efficiency of the internal polymersolvent phase into the external phase. ${ }^{20-22}$ An increase in the viscosity of the internal phase with increased amount of polymer also provides resistance for mass transfer and in turn diffusion of polymer solvent phase into the external phase, leading to particle enlargement. The zeta potential values of the nanoparticle suspension are presented in Table 2. All formulations exhibited strongly positive zeta potential values due to polycationic Eudragit ${ }^{\circledR}$ EPO comprising various ammonium groups. The increased zeta potential values in initial batches may be attributed to Eudragit ${ }^{\circledR}$ EPO available at the surface of the particles due to high viscosity of the external aqueous phase. The subsequent decline in values of zeta potential is an inverse function of particle size. ${ }^{23}$ As solid state pharmaceutics have many advantages over liquid formulations, mainly improved physicochemical stability and less susceptibility to microbial contamination, attempts were made to obtain dry powder nanoparticle suspensions by lyophilization. Based on the results of the factorial design batch $\mathrm{F} 6$ having drug content of $88.36 \pm 0.075 \%$, encapsulation efficiency of $94.28 \pm 0.198 \%$, and zeta potential of $26.2 \pm 0.208 \mathrm{mV}$ was further processed to obtain dry powder. When it was compared with the blank batch no significant variations in particle size or zeta potential were observed (Table 2). The lyophilized nanoparticles (F6)

Table 1. Coded levels and actual values of the variables along with the measured responses of the $3^{2}$ factorial design

\begin{tabular}{|c|c|c|c|c|c|c|}
\hline Batches & \multicolumn{2}{|c|}{ Coded levels } & $\begin{array}{l}\text { Concentration of Eudragit }{ }^{\oplus} \\
\text { EPO }(\% \mathrm{w} / \mathrm{v})\end{array}$ & $\begin{array}{l}\text { Concentration of Pluronic }{ }^{\circledast} \\
\text { F-68 }(\% \mathrm{w} / \mathrm{v})\end{array}$ & $\begin{array}{l}\text { Drug content }{ }^{\#} \\
(\%)\end{array}$ & $\begin{array}{l}\text { Entrapment } \\
\text { efficiency\# (\%) }\end{array}$ \\
\hline Etoposide & $\mathrm{X} 1$ & $\mathrm{X} 2$ & - & - & - & - \\
\hline $\mathrm{F} 2$ & -1 & 0 & 0.3 & 0.5 & $67.43 \pm 0.075$ & $54.40 \pm 0.150$ \\
\hline F3 & -1 & +1 & 0.3 & 0.6 & $72.87 \pm 0.015$ & $59.97 \pm 0.198$ \\
\hline F5 & 0 & 0 & 0.45 & 0.5 & $86.25 \pm 0.075$ & $88.23 \pm 0.276$ \\
\hline F6 & 0 & +1 & 0.45 & 0.6 & $88.36 \pm 0.075$ & $94.28 \pm 0.198$ \\
\hline F7 & +1 & -1 & 0.6 & 0.4 & $89.90 \pm 0.080$ & $89.95 \pm 0.202$ \\
\hline F8 & +1 & 0 & 0.6 & 0.5 & $87.66 \pm 0.130$ & $94.42 \pm 0.430$ \\
\hline
\end{tabular}

${ }^{\#}$ All the determinations were performed in triplicate and values were expressed as mean \pm standard deviation, $\mathrm{n}=3 ; \mathrm{X} 1$ : Polymer Eudragit ${ }^{\circledR}$ EPO; $\mathrm{X} 2$ : Stabilizer Pluronic ${ }^{\circledR}$ F-68

Table 1a. Prediction of regression value

\begin{tabular}{llllllll} 
Variable & Constant & $\mathrm{X}_{1}$ & $\mathrm{X}_{2}$ & $\mathrm{X}_{1} \mathrm{X}_{2}$ & $\mathrm{X}_{1} \mathrm{X}_{1}$ & $\mathrm{~F}$ & $\mathrm{R}^{2}$ \\
\hline & & & & & & & \\
Drug content (R1) & 85.6067 & 11.2727 & 2.7933 & 2.7364 & 6.9473 & 721.12 & 0.9986 \\
\hline Entrapment efficiency (R2) & 88.1100 & 19.1767 & 4.6033 & - & 14.4633 & 194.77 & 0.9915 \\
\hline
\end{tabular}


have an average particle size of $131.4 \pm 0.057 \mathrm{~nm}$. The almost twofold increase in size of particles could be due to changes in the internal structure of the particles, originated during the freeze drying process caused by the formation of ice crystals in the water phase, or, more likely, to particle aggregation during freeze drying, resulting in poor redispersion. ${ }^{24}$ Figures 2, 3 and 4 show the DSC thermogram of etoposide and lyophilized nanoparticles. Etoposide exhibits a sharp melting endotherm at $266.9^{\circ} \mathrm{C}(78.39 \mathrm{~J} / \mathrm{g})$, whereas the thermogram of the lyophilized nanoparticle suspension displays a sharp endotherm at $262.7^{\circ} \mathrm{C}$ $(60.38 \mathrm{~J} / \mathrm{g})$. It explains the monotectic behavior of the system, where the drug gets completely dissolved below its melting temperature in a molten mass of the excipients. Similar behavior was also reported for the nifedipine with Pluronic ${ }^{\circledR}$ F-68, Gelucire, and paracetamol with PEG. ${ }^{25,26}$ The PXRD diffraction patterns, as shown in Figure 4, reveal characteristic peaks at 4.2, 9.46, 10.22, 13.18, 16.15, 17.08, 17.67, 19.26, 19.89, $22.14,23.03,23.67,24.17$, and 26.78 , which can be inferred to show a high crystalline structure. The complete disappearance of peaks in lyophilized powder may be due to the formation of an amorphous complex while undergoing the nanoprecipitation with an intermolecular interaction occurring within the matrix. Peaks of reduced intensity were observed in the physical mixture. The intermolecular interaction in the nanoparticle suspension was established by FTIR as shown in Figures 5 and 6. Etoposide exhibits the characteristic intensities of a $\mathrm{C}=\mathrm{O}$ stretching absorption band at $1764 \mathrm{~cm}^{-1}$ and the $\mathrm{O}-\mathrm{H}$ stretch at $3452 \mathrm{~cm}^{-1}$. However, FTIR spectra of the lyophilized powder showed a $\mathrm{C}=\mathrm{O}$ stretching absorption band of etoposide and $\mathrm{O}-\mathrm{H}$ stretching. These result suggested no interaction between drug and polymer. The surface topography of the nanoparticle suspension was studied using SEM, which displayed uniform sized spherical nanoparticles with size range correlating with particle size studies. A SEM photograph of nanoparticles is

Table 2. Zeta potential, particle size, and polydispersity of polymeric nanoparticles

\begin{tabular}{llll} 
Batches & $\begin{array}{l}\text { Zeta potential* } \\
(\mathrm{mV})\end{array}$ & $\begin{array}{l}\text { Mean particle } \\
\text { size* }(\mathrm{nm})\end{array}$ & Polydispersity* \\
\hline Etoposide & - & $1120 \pm 0.200$ & $1.547 \pm 0.005$ \\
\hline F1 & $18.30 \pm 0.135$ & $114.4 \pm 0.305$ & $0.734 \pm 0.002$ \\
\hline F2 & $19.46 \pm 0.305$ & $125.5 \pm 0.862$ & $0.715 \pm 0.001$ \\
\hline F3 & $20.2 \pm 0.115$ & $134.6 \pm 0.200$ & $0.707 \pm 0.002$ \\
\hline F4 & $24.6 \pm 0.200$ & $128.5 \pm 0.100$ & $0.564 \pm 0 . .005$ \\
\hline F5 & $25.6 \pm 0.200$ & $129.3 \pm 0.100$ & $0.548 \pm 0.001$ \\
\hline F6 & $26.2 \pm 0.208$ & $131.4 \pm 0.057$ & $0.522 \pm 0.001$ \\
\hline F7 & $22.3 \pm 0.152$ & $134.4 \pm 0.115$ & $0.693 \pm 0.001$ \\
\hline F8 & $23.6 \pm 0.200$ & $135.3 \pm 0.152$ & $0.684 \pm 0.002$ \\
\hline F9 & $24.60 \pm 0.152$ & $136.7 \pm 0.100$ & $0.353 \pm 0.005$ \\
\hline Blank (F6) & $26.50 \pm 0.208$ & $136.3 \pm 0.208$ & $0.526 \pm 0.002$ \\
\hline$* A 1$ ( & & &
\end{tabular}

*All the determinations were performed in triplicate and values were expressed as mean \pm standard deviation, $n=3$ shown in Figure 7. The in vitro drug release profiles of etoposide and lyophilized nanoparticles in phosphate $\mathrm{pH} 7.4$ buffer are shown in Figures 8, 9, and 10. The formulated nanoparticles showed the most favorable release within $24 \mathrm{~h}$. Only $14.09 \pm 0.19 \%$ drug release was obtained from the raw material of etoposide. At $24 \mathrm{~h}$, the drug release was $79.09 \pm 0.58 \%, 81.34 \pm 0.37 \%$, $82.81 \pm 0.63 \%, \quad 94.22 \pm 0.56 \%, \quad 96.02 \pm 0.31 \%, \quad 99.22 \pm 0.50 \%$, $86.02 \pm 0.18 \%, 89.90 \pm 0.33 \%$, and $91.93 \pm 0.28 \%$ for F1, F2, F3, F4, F5, F6, F7, F8, and F9, respectively. This followed a steady state drug release pattern.

These above data showed that formulation F6 released the drug most at the end of $24 \mathrm{~h}$. The release rate of Etoposide decreased with increasing concentration of Eudragit. However, an increase in the rate of release was found with increasing amount of Pluronic.

As compared with pure drug, lyophilized nanoparticles showed a significant increase in dissolution rate with maximum and complete drug release with F6. However, lyophilization retarded the drug release. The retardation of drug release of lyophilized formulation is probability due to aggregation of the particles in lyophilization, but still particles exhibited size below $1 \mu \mathrm{m}$. The kinetics of in vitro drug release was determined by applying the drug release data to various kinetic models such as zero order, first order, Higuchi, and Korsmeyer-Peppas. The results obtained are shown in Table 3.

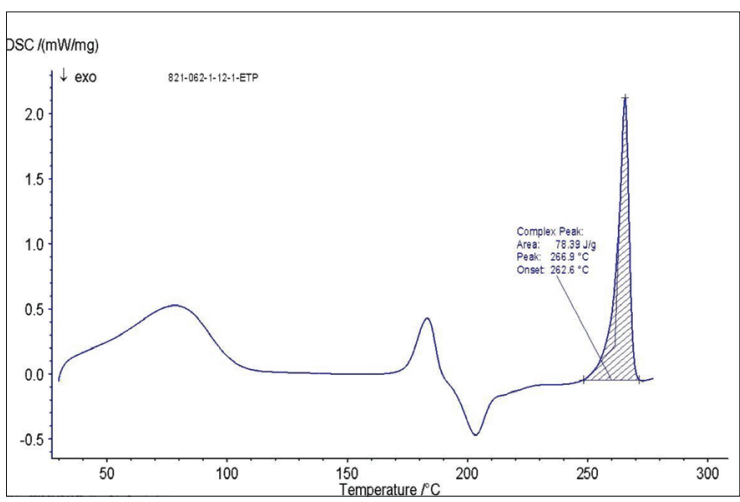

Figure 2. DSC thermogram of etoposide

DSC: Differential scanning calorimetric

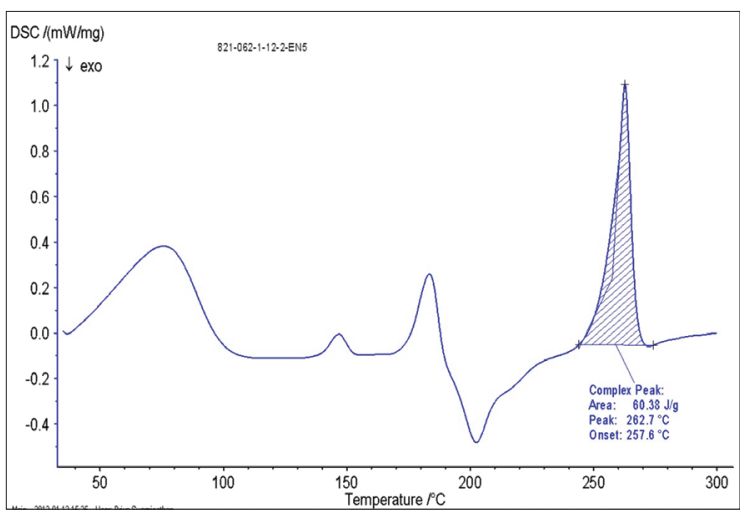

Figure 3. DSC thermogram of etoposide nanoparticles 
The optimized nanoparticle suspension was subjected to a stability study at $4 \pm 1^{\circ} \mathrm{C}$. During that stability study, no significant difference in drug content $(87.69 \pm 0.043 \%$,

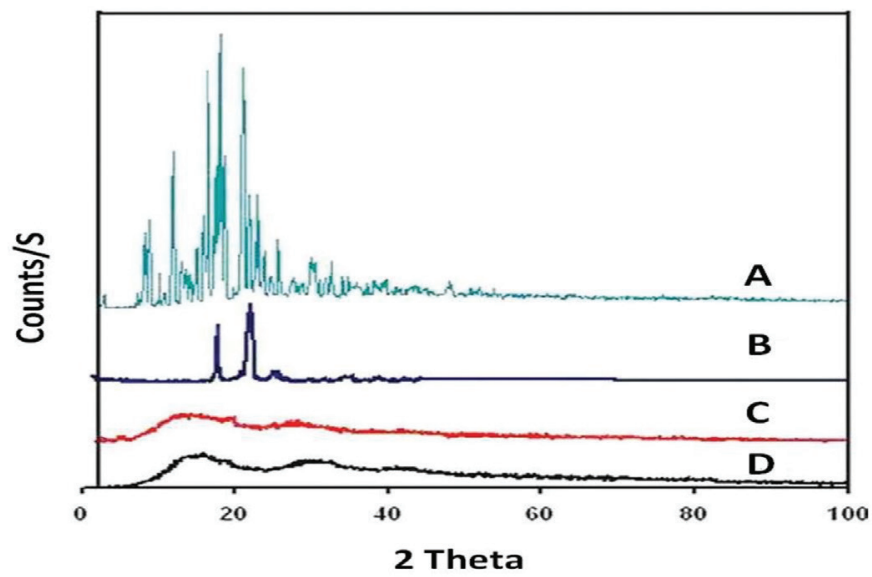

Figure 4. XRD spectra of (A) etoposide, (B) physical mixture of etoposide and polymers, (C) polymeric nanoparticles (before lyophilization), and (D) etoposide loaded polymeric nanoparticles (after lyophilization)

XRD: X-ray diffraction

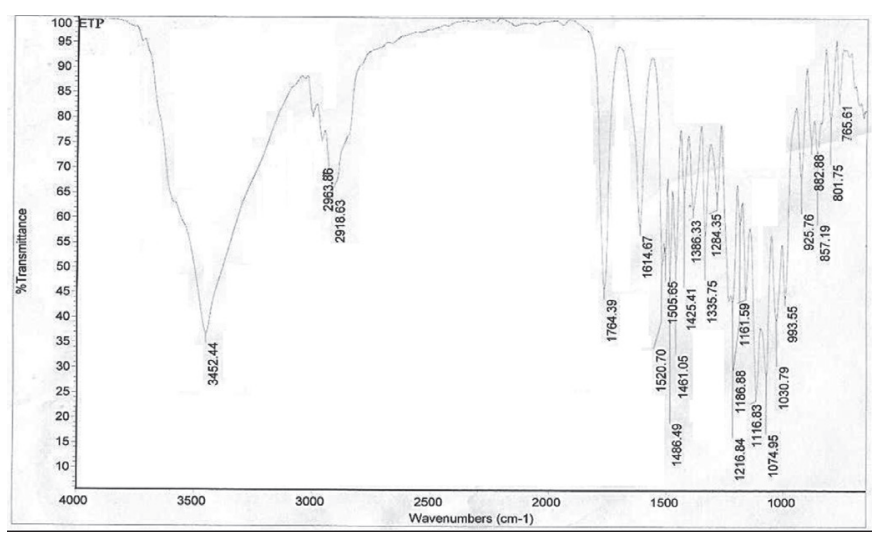

Figure 5. FTIR spectrum of etoposide

FTIR: Fourier transform infrared encapsulation efficiency $(93.32 \pm 0.015 \%)$, or in vitro drug release $(97.92 \pm 0.037 \%)$ was observed over the period of 1 year. The stability results are shown in Table 4. There was no significant difference in physical instability like change in appearance and settling behavior was also observed. The average targeting efficiency of drug loaded nanoparticles was $41.88 \pm 0.030 \%$ of the injected dose in the liver, $25.66 \pm 0.320 \%$ in the spleen, $13.82 \pm 0.090 \%$ in the lungs, $4.52 \pm 0.300 \%$ in the kidney, and $4.18 \pm 0.490 \%$ in the brain as compared to the concentration of pure drug of $28.47 \pm 0.041 \%$ in the liver, $16.40 \pm 0.080 \%$ in the spleen, $13.79 \pm 0.195 \%$ in the lungs, $11.83 \pm 0.065 \%$ in the kidney,

\begin{tabular}{lll}
$\begin{array}{l}\text { Table 4. Stability testing parameters of optimized nanoparticles } \\
\text { (F6) }\end{array}$ & $\begin{array}{l}\text { Fresh } \\
\text { formulation }\end{array}$ & $\begin{array}{l}\text { Storage condition } \\
\text { at } 4 \pm 1^{\circ} \mathrm{C} \text { (end of } 1 \text { year) }\end{array}$ \\
\hline Evaluation parameters & $88.36 \pm 0.075$ & $87.69 \pm 0.043$ \\
\hline \% Drug content & $94.28 \pm 0.190$ & $93.03 \pm 0.020$ \\
\hline \% Entrapment efficiency & $99.22 \pm 0.50$ & $97.92 \pm 0.037$ \\
\hline Percentage drug release & $92.3)$
\end{tabular}

${ }^{*}$ Results are expressed as mean \pm standard deviation $(n=3)$

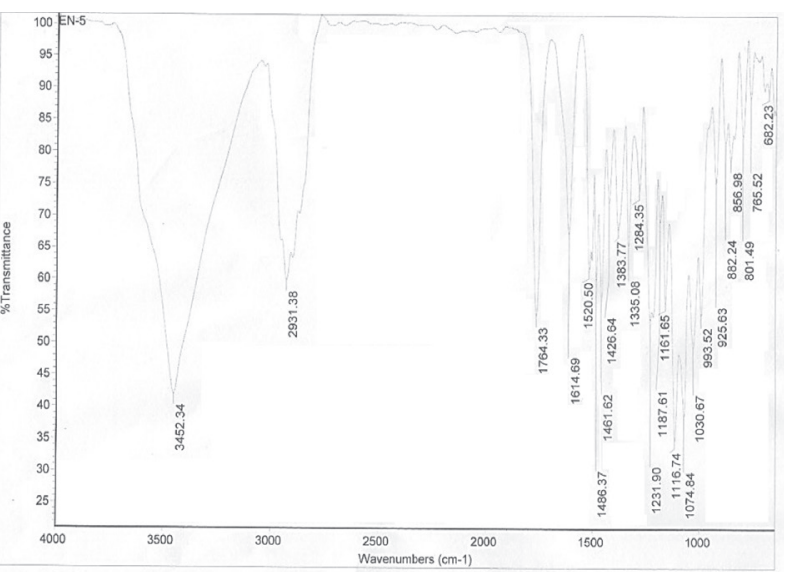

Figure 6. FTIR spectrum of etoposide nanoparticles

\section{Table 3. Kinetics of in vitro drug release profile for all etoposide nanoparticles}

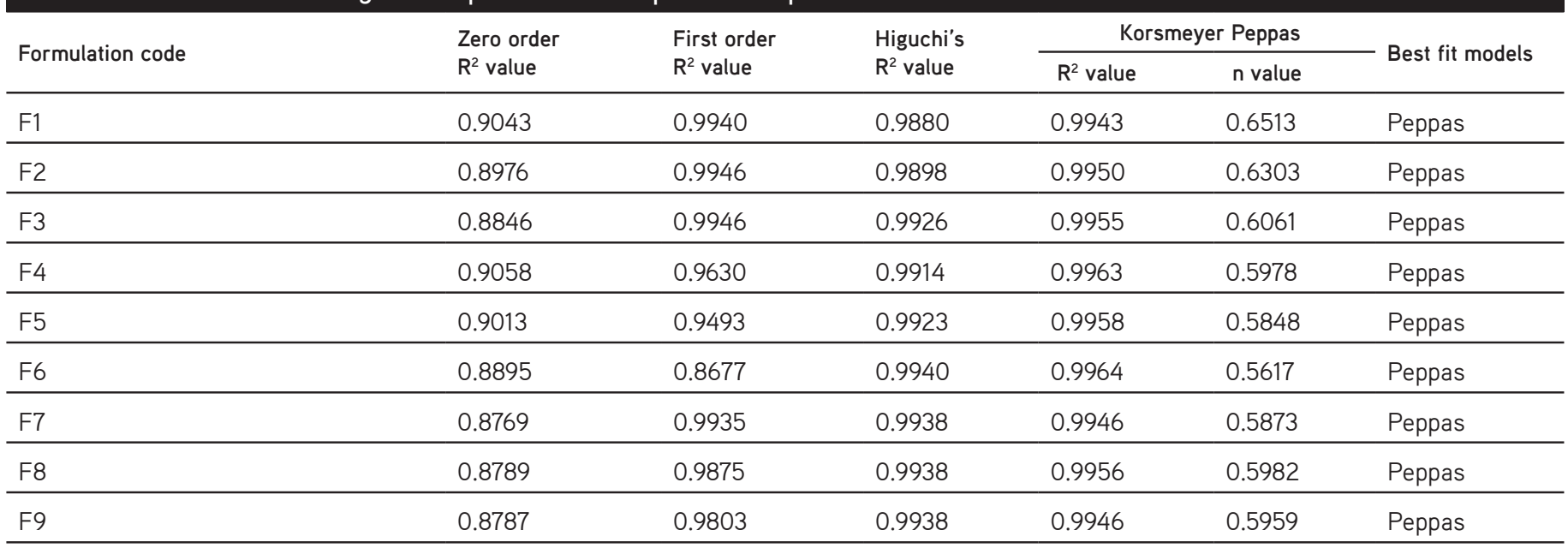

${ }^{*}$ Results are expressed as mean \pm standard deviation $(n=3)$ 


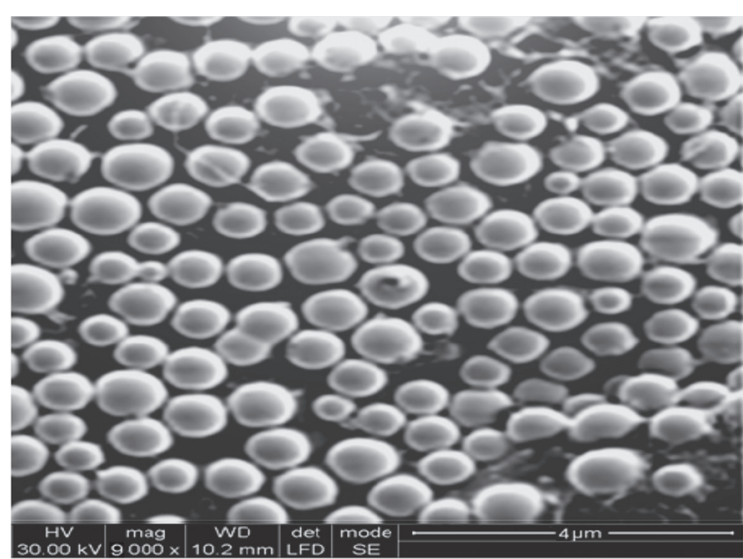

Figure 7. SEM photograph of the etoposide nanoparticle suspension SEM: Scanning electron microscopy

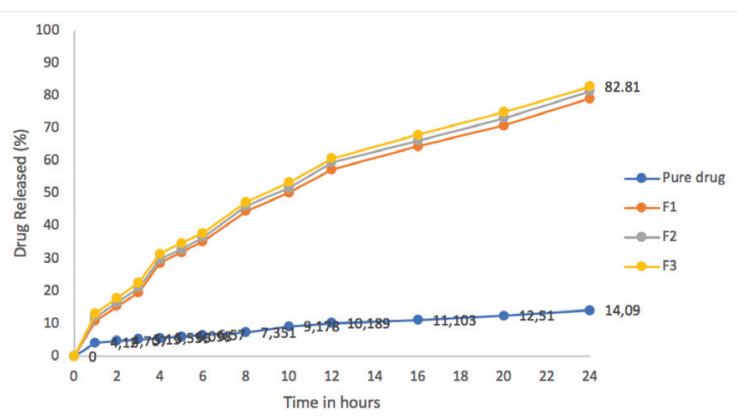

Figure 8. Comparative in vitro drug release of the etoposide nanoparticles (F1, F2, F3). All the values expressed as mean \pm standard deviation, $n=3$

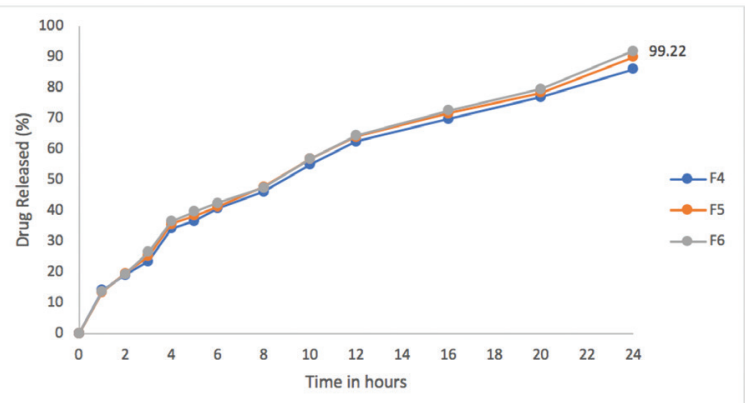

Figure 9. Comparative in vitro drug release of the etoposide nanoparticles (F4, F5, F6). All the values expressed as mean \pm standard deviation, $n=3$

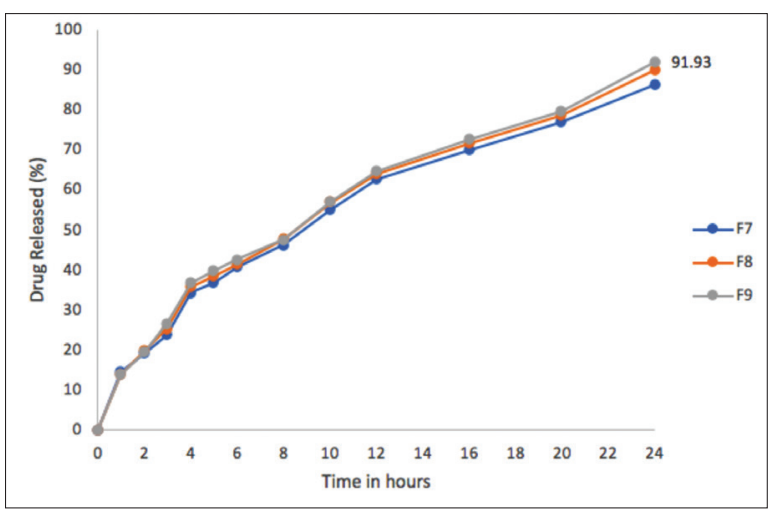

Figure 10. Comparative in vitro drug release of the etoposide nanoparticles (F7, F8, F9). All the values expressed as mean \pm standard deviation, $n=3$

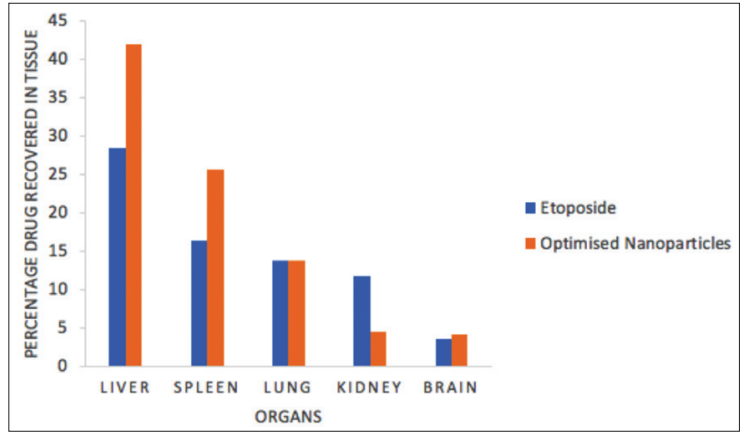

Figure 11. Comparative in vivo drug targeting. Each data point is the mean \pm standard deviation of 3 experiments

and $3.63 \pm 0.180 \%$ in the brain. The results are shown in Figure 11. The drug loaded nanoparticles showed preferential drug targeting to the liver followed by the spleen, lungs, kidney, and brain.

\section{CONCLUSIONS}

Generally, oral etoposide administration compared to intravenous administration may result in an improvement in the patient's quality of life and reduced costs. Several studies have confirmed the comparable safety and efficacy of oral and intravenous etoposide. However, greater use of oral etoposide is limited by its incomplete and variable bioavailability. The present study utilized particle engineering to improve the primary properties of etoposide. The novel polymeric nanoparticles containing etoposide were prepared by nanoprecipitation. The polycationic polymers Eudragit ${ }^{\circledR}$ EPO and Pluronic ${ }^{\circledR}$ F-68 as stabilizer can be used to obtain stable nanoparticle suspensions. In addition, ionic interactions between cationic polymers with GI mucosa may improve bioavailability. The drug:polymer ratio and concentration of stabilizer were found to influence the drug content and entrapment efficacy of etoposide nanoparticles but the concentration of stabilizer had great influence of both dependent variables. In the in vitro drug release study of selected factorial formulations F6 showed $99.22 \%$ drug release in $24 \mathrm{~h}$. The drug release was found to follow Peppas release kinetics with a Fickian diffusion mechanism for all batches. Therefore, it was concluded that etoposide nanoparticles could be effective in sustained release.

These results show that the etoposide loaded polymeric nanoparticles showed preferential targeting of the drug to the liver followed by the spleen, lungs, kidney, and brain. It also revealed that, as compared to pure drug, higher concentrations of drug targeted the organs like the liver and lungs after administering the dose in the form of nanoparticles. This may be attributed to the high macrophage load in these organs and large size of the liver as compared to the spleen and lungs.

The relatively high concentration of drug etoposide present in the liver suggests its usefulness in the targeting of liver cancer. The etoposide nanoparticles of smaller particle size coupled with the prolonged blood circulating property could be a beneficial delivery system for tumor targeting. Further investigations are required on the anticancer activity and pharmacokinetics of 
selected factorial formulations of F6 etoposide nanoparticles. Those studies are in progress in our laboratory.

\section{ACKNOWLEDGMENTS}

Financial support from the Tamilnadu Dr. M.G.R. Medical University, [Sw (1)/26221/2015] Chennai, India, is gratefully acknowledged. The Director, Indian Institute of Technology, Chennai, India, is acknowledged for providing necessary facilities to carry out the analytical studies. The authors are also thankful to Azidus Laboratories Ltd, Chennai, India, for their help in carrying out the animal studies.

Conflict of Interest: No conflict of interest was declared by the authors.

\section{REFERENCES}

1. Montecucco A, Biamonti G. Cellular response to etoposide treatment. Cancer Lett. 2007;252:9-18.

2. Ezoe S. Secondary leukemia associated with the anti-cancer agent, etoposide, a topoisomerase II inhibitor. Int J Environ Res Public Health. 2012;9:2444-2453.

3. McLeod HL, Evans WE. Clinical pharmacokinetics and pharmacodynamics of epipodophyllotoxins. Cancer Surv. 1993;17:253-268.

4. Rodman JH, Murry DJ, Madden T, Santana VM. Altered etoposide pharmacokinetics and time to engraftment in pediatric patients undergoing autologous bone marrow transplantation. J Clin Oncol. 1994;12:2390-2397.

5. Hande KR. Etoposide pharmacology. Semin Oncol. 1992;19(6 Suppl 13):39.

6. Joel SP, Shah R, Slevin ML. Etoposide dosage and pharmacodynamics. Cancer Chemother Pharmacol. 1994;34(Suppl):69-75.

7. Chellampillai B, Pawar AP. Improved bioavailability of orally administered andrographolide from $\mathrm{pH}$-sensitive nanoparticles. Eur J Drug Metab Pharmacokinet. 2011;35:123-129.

8. Huang KJ, Zhu CH. The production and characteristics of solid lipid nanoparticles (SLNs). Biomaterials. 2003;24:1781-1785.

9. Kaliks R, Guerra C, Giglio AD. Efficacy and toxicity of mitoxantrone and oral etoposide in the treatment of hormone refractory prostate cancer: pilot study. Einstein (Sao Paulo). 2010;8:336-338.

10. Patloll RR, Vobalaboina V. Folate-targeted etoposide-encapsulated lipid nanospheres. J Drug Target. 2008;16:269-275.

11. Patlolla RR, Vobalaboina V. Pharmacokinetics and tissue distribution of etoposide delivered in parenteral emulsion. J Pharma Sci. 2005;94:437445.
12. Abdelbary G, Fahmy RH. Diazepam loaded solid lipid nanoparticles: design and characterization. AAPS PharmScieTech. 2009;10:211-219.

13. Kreuter J. Nanoparticles in Colloidal Drug Delivery Systems. New York; Marcel Dekker Inc; 1994:2019-220.

14. Huynh NT, Passirani C, Saulnier P, Benoit JP. Lipid nanocapsules: A new platform for nanomedicine. Int J Pharm. 2009;379:201-209.

15. Xing J, Zhan, D, Tan T. Studies on the oridonin-loaded poly(D,L-lactic acid) nanoparticles in vitro and in vivo. Int J Biol Macromol. 2007;40:153158.

16. Lee ES, Oh YT, Youn YS, Nam M, Park B, Yun J, Kim JH, Song HT, Oh KT. Binary mixing of micelles using pluronics for a nano-sized drug delivery system. Colloids Surf B Biointerfaces. 2011;82:190-195.

17. Kocbek P, Baumgartner S, Kristl J. Preparation and evaluation of nanosuspensions for enhancing the dissolution of poorly soluble drugs. Int J Pharm. 2006;312:179-186.

18. Ubrich N, Schmidt C, Bodmeier R, Hoffman M, Maincent P. Oral evaluation in rabbits of cyclosporin-loaded Eudragit RS or RL nanoparticles. Int J Pharm. 2005;288:169-175.

19. Wu TH, Yen FL, Lin LT, Tsai TR, Lin CC, Cham TM. Preparation, physicochemical characterization, and antioxidant effects of quercetin nanoparticles. Int J Pharm. 2008;346:160-168.

20. Haznedar S, Dortunc B. Preparation and in vitro evaluation of Eudragit microspheres containing acetazolamide. Int J Pharm. 2004;269;131-140.

21. Hoffart V, Ubrich N, Simonin C, Babak V, Vigneron C, Hoffman M, Lecompte T, Maincent P. Low molecular weight heparin-loaded polymeric nanoparticles: formulation, characterization, and release characteristics. Drug Dev Ind Pharm. 2002;28:1091-1099.

22. Rodriguez SG, Allemann E, Doelker E, Fessi H. Versatility of three techniques for preparing ibuprofen-loaded methacrylic acid copolymer nanoparticles of controlled sizes. Pharm Res. 2005;15:347-354.

23. Dillen K, Vandervoort J, Van den Mooter G, Ludwig A. Evaluation of ciprofloxacin-loaded Eudragit RS100 or RL100/PLGA nanoparticles. Int J Pharm. 2006;314:72-82.

24. Kocbek P, Baumgartner S, Kristl J. Preparation and evaluation of nanosuspension for enhancing the dissolution of poorly water soluble drugs. Int J Pharm. 2006;312:179-186.

25. Vippagunta SR, Maul KA, Tallavajhala S, Grant DJ. Solid-state characterization of nifedipine solid dispersions. Int $\mathrm{J}$ Pharm. 2002;236:111-123.

26. Lloyd GR, Craig DQ, Smith $A$. An investigation into the melting behavior of binary mixes and solid dispersions of paracetamol and PEG 4000. J Pharm Sci. 1997;86:991-996. 